\title{
Obituary
}

Notwithstanding his highly successful scientific career he was modest and unaffected. Many a man would raise a fortune on a method of treatment such as he recently introduced for otosclerosis ; but the making of money was of little interest to him ; he was more concerned as to the validity of his observations than their potential pecuniary value.

Albert Gray was a lovable man, of a cheery and sociable disposition and possessed of the quality of politesse de cour. He had many friends at home and abroad. Outside his professional work he was interested in various forms of sport. He found great inspiration and delight in Shakespeare and in some of the byways of literature. Above all he was a keen naturalist and was happiest when on holiday on the shores of the sea lochs of Argyll. Throughout life and up to the last he preserved his youthful enthusiasms and in a large measure his physical activity. Beloved of the gods, he died young.

He is survived by his two sons: the elder is Headmaster of Bootham School, York, and the younger is a doctor in Haslemere, Surrey.

A.B.K.

\section{DR. TOMASO BOBONE}

San Remo (I $852-1935)$

IN pre-war days there was a flourishing English Colony in San Remo. At one time, at the end of last century, it was large enough to supply good practices to three English Physicians. They and their patients were long indebted to the services of the Otolaryngologist who has just died at the age of 83 . Dr. Bobone was one of the kindest and most genial of men. He was fond of our country-people and knew our language so well that, even up to quite recently, he was a regular contributor to the special publications in Italy of abstracts taken from this Journal. He retained all his faculties and his cheerful spirit until near his death. Indeed, only three days before this occurred in October, he wrote to an old friend telling of some trouble in his foot, which interfered with his regular walk and ended his letter with the words: "Otherwise I feel very well, except that I have to recognize that my muse is becoming old."

FREDERICK HIBBERT WESTMACOTT, C.B.E., D.L., F.R.C.S. IT is with regret that we record the death on December 2oth, of Mr. F. H. Westmacott. Born in Manchester in 1867 , and educated at the Manchester Grammar School, Mr. Westmacott obtained his medical education at the Manchester University, qualifying with 


\section{Obituary}

the M.R.C.S., diploma in $\mathrm{I} 890$, and obtaining the F.R.C.S. (England), four years later. After holding various local hospital resident appointments, Westmacott then visited the Clinics at Vienna to study the diseases of the Ear, Nose and Throat, returning to Manchester a few months later to engage in consulting practice in this speciality.

As there was no available hospital appointment, Mr. Westmacott for a time was an anæsthetist at the Pendlebury Children's Hospital, but later took over a private venture founded in $\mathrm{I} 888$ by Dr. McKeown, and by his characteristic energy and organizing ability, finally succeeded in establishing it as the St. John's Hospital for the Ear, with a representative Honorary Medical Staff and Board of Governors, which in I9I3 received the full recognition of the Charity Commissioners. In I9I3 he was appointed to the Honorary Staff of the Aural Department of the Manchester Royal Infirmary, and later was appointed University Lecturer in Nose and Throat diseases-appointments which he held until his sixtieth year.

From his early youth, Westmacott had always been keenly interested in military affairs, and for several years commanded the Manchester University Battalion. At the outbreak of the Great War, as registrar, he assisted in the administration of the and Western General Hospital, with its headquarters in Manchester, and in I9I5, succeeded to its full command. This was a type of work dear to his heart, affording him every opportunity of revealing his organizing capacity and unfailing tact.

After mobilizing and for a time commanding in France, the 57th General Hospital, he was in I9I8 appointed A.D.M.S., in Marseilles, where he remained until the Armistice. In recognition of his military services, he was mentioned several times in dispatches, received the honour of C.B.E., and later, was appointed a Deputy-Lieutenant for the County of Lancaster.

In his earlier days, he was created a Knight of Grace of the Order of St. John of Jerusalem, and his wife a Lady of Grace of the same order.

An honour which gave him particular pleasure was when in 1927, he was appointed an Honorary Surgeon to His Majesty the King.

Among many other interests, Westmacott was Chairman of the South-East Lancashire Advisory Council of the British Legion, and of the Manchester and Salford Poppy Day Collection Fund, and was a prominent Freemason, holding office as Assistant Provincial Grand Master of the East Lancashire Division and a Past Grand Deacon of the Grand Lodge of England.

Such was his untiring energy that in spite of his many civic and social activities, Westmacott acquired a considerable private 


\section{Letters to the Editor}

consulting practice and, particularly in his earlier days, made many contributions to the scientific side of his profession. Chief amongst the latter was his well-known work on "Chronic Hyperplasia of the Superior Maxilla" (Trans. Internat. Cong. Med. London, I9r3), and his contribution in I9I2 on diseases of the nasal accessory sinuses, was published in Latham and English's System of Medicine.

He was a member of the B.M.A., and acted as Secretary of the Section of Otology at the Association's meeting in Manchester in 1902, and Vice-President at the London meeting in I9Io. When in I929, the Association met in Manchester, Westmacott was President of his special section and Chairman of the Arrangements Committee.

Such was his charming personality that he acquired, and retained around him many friends. Evidence of the public esteem was the well-attended funeral service held at the Manchester Cathedral, when representatives of the various civic, military, medical, and charitable organizations in which he had played so prominent a part came to pay a last tribute to their departed friend.

F. Holt Diggle.

\section{LETTERS TO THE EDITOR}

To ThE EDITOR,

The Journal of Laryngology and Otology.

DEAR SIR,-As the review of the book on Speech in Childhood in the December, I935, number of the Journal was unsigned, we are unable to communicate directly with the anonymous reviewer and we therefore ask you to give us the courtesy of your columns in order that the following small point may be made clear.

Your reviewer states: "Fig. Io is unfortunate as it indicates stretching of the vocal cords, as illustrated by a weight pulling the arytenoids backwards, acting as an 'inner tensor, thyro-arytenoid muscle ':"

If your reviewer will kindly look at the diagram again, he will observe that the weight is actually pulling the anterior end of the vocal cord forwards. The word "stretching" is not used at all, and on page 22 it is stated that " the thyro-arytenoid muscles by their contraction impart to the vibrating edge of the vocal cords the varying degree of hardness or elasticity which is necessary for the production of voice". The use of an elastic membrane, in our model, to represent the cords has misled your reviewer into imagining that we regard the vocal cord as physically comparable to an elastic band but we do not think that the average reader is likely to misconstrue the description, as he will not find anywhere in the book the slightest indication that the vocal cords undergo I38 